(2) Open Access Full Text Article

LETTER

\title{
Appropriate blood pressure for the "old-old" (85 years and older)
}

This article was published in the following Dove Press journal:

Clinical Interventions in Aging

26 June 2014

Number of times this article has been viewed

\author{
Albert J Finestone \\ Temple University, School of Medicine, \\ Philadelphia, PA, USA
}

\section{Dear editor}

Treating hypertension in patients over the age of 85 years, ie, the "old-old", presents a challenge that is different from that encountered when treating any other age group. In 2010, individuals aged over 85 years were estimated to comprise $1.85 \%$ of the US population, with an estimate of $2.03 \%$ projected for $2025 .{ }^{1}$ Clearly, this is a small percentage, but not an insignificant number. When treating hypertension in patients over the age of 85 years, the usual target blood pressure is $150 / 80 \mathrm{mmHg}$ for reduction of the risk of stroke, heart attack, and other cardiovascular events. ${ }^{2}$ In medical practice today, blood pressure is measured by a nurse or health worker using an automated blood pressure device, but not after a short rest, sitting or standing (as recommended to measure orthostatic hypotension, particularly if the patient is on treatment with antihypertensive medications). I will continue to emphasize orthostatic hypotension, since during sleep, the elderly - either under medication treatment, or not - frequently get out of bed during the night to urinate, which is associated with the usual drop in blood pressure during sleep.

Primary care physicians, nurse practitioners, and others caring for the elderly must recalibrate which target and which range to use to treat this group of patients. ${ }^{3}$ My feeling is "less is more" in this group of patients. Perhaps one might consider the mantra of the legendary coach of the Green Bay Packers, ie, "When you throw a foot ball, three things could happen, and two are bad". This is not a bad maxim when writing a prescription.

Moving on to consideration of the specifics of this letter, I will present evidence for "less is more" in order to prevent the serious complications of hypertension in the elderly and other age groups. In a recent issue of the Philadelphia Inquirer, two distinguished physicians (RT Townsend, Hypertension Program, Hospital University Penn Program, and Muriel L Jessup, Penn Heart and Vascular Center) recommended treatment for people older than 60 years, those with a systolic blood pressure of $150 \mathrm{mmHg}$, those with diabetes or kidney disease, and those with a blood pressure greater than $140 / 90 \mathrm{mmHg}$.

In a recent issue of $J A M A$, a paper entitled "Updated guidelines for the management of high blood pressure" states that hypertension is a major risk factor for cardiovascular disease and stroke, but approximately $50 \%$ are not adequately controlled. In the US, the strong beliefs of patients, physicians, and pharmaceutical companies make the production of guidelines for managing hypertension a progressively more difficult and controversial process. ${ }^{4}$ Further, it has been commented that current performance measures for blood pressure control modeled after the Joint National Committee guidelines 
indicate that a clinician is expected to lower blood pressure in a hypertensive patient to $<140 / 90 \mathrm{mmHg}$ (or at least treat with 2-3 antihypertensive medications). ${ }^{4}$ A potential unintended consequence of this target is that it could encourage physicians to become more aggressive in their management of older patients, simply to meet a specific metric.

I am in no way suggesting collusion to increase the use of medication to treat hypertension in the elderly. A recent essay entitled "Big Pharma-Big Fines/Bigger Profits" indicates that the American Hospital Association spends lots of money to lobby pharmaceutical companies. ${ }^{5}$

My final point is that a study from the University of Leiden in the Netherlands has reported that a systolic blood pressure of $180 \mathrm{mmHg}$ is associated with resilience to physical and cognitive decline in patients with pre-existing disability. ${ }^{6}$

\section{Disclosure}

The author reports no conflicts of interest relevant to this communication.

\section{References}

1. Editorial. Lessons of the Census. New York Times. July 27, 2010. Available from: http://www.nytimes.com/2010/07/27/opinion/27tue3. html?_r=0. Accessed May 29, 2014.

2. Beckett NS, Peters R, Fletcher AE, et al; HYVET Study Group. Treatment of hypertension in patients 80 years of age or older. N Engl J Med. 2008;358:1887-1898.

3. Finestone AJ. Are new parameters needed in treating the "old-old". Clin Geriatr. 2009;17:46-47.

4. Bauchner H, Fontanarosa PB, Golub RM, et al. Updated guidelines for management of high blood pressure. JAMA. 2014;311:477-478.

5. Bukata WR. Big Pharma-Big Fines/Bigger Profits. Essay. Primary Care Medical Abstracts. 2014;23:1-4.

6. Sabayan B, Oleksik AM, Maier AB, et al. High blood pressure in resilience to physical and cognitive decline in oldest old: the Leiden $85+$ study. J Am Geriatr Soc. 2013;60:2014-2019.
Clinical Interventions in Aging

\section{Publish your work in this journal}

Clinical Interventions in Aging is an international, peer-reviewed journal focusing on evidence-based reports on the value or lack thereof of treatments intended to prevent or delay the onset of maladaptive correlates of aging in human beings. This journal is indexed on PubMed Central, MedLine,

\section{Dovepress}

CAS, Scopus and the Elsevier Bibliographic databases. The manuscript management system is completely online and includes a very quick and fair peer-review system, which is all easy to use. Visit http://www.dovepress. com/testimonials.php to read real quotes from published authors. 